\title{
From the Backstage of War: the Struggle of Mothers in the Favelas of Rio de Janeiro
}

\author{
Vinícius Santiago* \\ Marta Fernández**
}

\begin{abstract}
This article analyses the political status of mothers whose children have been killed by members of the Brazilian military police and armed forces in the favelas of Rio de Janeiro in the course of the 'war against drugs'. These mothers bear witness to the reality of state interference in the lives of their families. The loss of a child interrupts their intimate affective bonds and temporal linkages between the past, present and future, thereby requiring a resignification of the meaning and temporality of their lives. The war waged by the state and the mothers' struggle for justice gives rise to a social dynamic that positions these mothers in a reordering of space and a redefinition of time, creating a spatio-temporal existence of pain, despair and hope.
\end{abstract}

Keywords: War; Favelas; State; Mothers; Temporality.

\section{Introduction}

The urban contexts in which the symbolic repertoire of war is mobilised in Rio de Janeiro, and the consequent demands for public order alongside militarised and repressive models of public security, revive an idea of pacification and guardianship long present in the colonial history of Brazil. It involves a statist logic of power that overwhelms, in violent and arbitrary ways, the rights of citizens living in favelas.

The protagonism of mothers whose sons have been killed in the course of the 'war against drugs' becomes part of the public space in so far as the solidarity created among them in their search for justice weaves a narrative of political struggle that calls into question the masculinist and sovereign prerogative of the nation-state to protect its citizens and promote social order. Despite their traumatic experiences, some of these mothers accept the risks of engaging in this struggle (some are also killed, as we will show later) in an attempt to overcome their pain, and speak out on behalf of their sons as well as themselves. The war waged by these mothers disputes the space and time destroyed by

\footnotetext{
* Pontifical Catholic University of Rio de Janeiro, Rio de Janeiro-RJ, Brazil; viniciuswbsantiago@gmail.com.

** Pontifical Catholic University of Rio de Janeiro, Rio de Janeiro-RJ, Brazil; martafygarcia@gmail.com.
} 
the police and the army, and makes public their pain over the loss of their children. This article focuses on these mothers, and their struggle for justice.

The temporal experiences of the state and the mothers are made manifest in a 'battlefield' occupied by two opposing forces: the state with its sovereign prerogative on the one side, and the mothers with their cry of pain on the other. The political dimension of this pain, as brought into the public space, is a condition for questioning the status quo attributed to the state and its institutional exercise of violence against these mothers.

This article seeks to problematise the naturalisation of this gendered perspective in as much as these mothers disrupt the condition of passivity attributed to them by demonstrating their agency via these political movements. They emerge from a condition of invisibility imposed on them by this frame of war by revealing the extreme impacts that armed violence has on their lives. Behind this structure of public (in)security are many faces, voices and lives, suffering the direct impacts of this war on their bodies (Moura 2010; Lacerda 2014).

This article ${ }^{1}$ is based on field work conducted in the favelas of Rio de Janeiro over the past two years. The work began in the favela of Manguinhos at the end of 2014 with an event in honour of Johnatha de Oliveira, a 19-year-old boy murdered by the military police earlier that year. The memory of Ana Paula, Johnatha's mother, weeping and crying out as she recalled events on the day her son was killed is an indelible one. This was a shocking introductory experience, which affected the rest of the field work. The mothers described outrageous scenes on the day of the murder in emotionally charged narratives. Significantly, they had a strong political sense that these events were driven by a state that not only allowed but actively perpetuated violence and murder. The notion of the 'state' occurs frequently in their speeches, and they seem to have a deep awareness that they have lost their sons in the name of the state. Extracts from their narratives appear below:

DG went missing on 22 April 2014. His dead body was hidden on purpose for 16 hours. He was murdered by the armed wing of the state. The body was hidden in a day care centre for 16 hours! (Maria de Fátima, Douglas Rafael da Silva Pereira’s mother).

Good evening everyone, to those who don't know me, I'm Deize Carvalho, Andreu's mother. Unfortunately, the same state that abandoned me when I grew up, this same state in which I once believed, tortured and killed my son Andreu on 1 January 2008 (Deize Carvalho, Andreu's mother).

The pain felt by those women, whose gravity is largely inaccessible beyond their social positions, was more than intimate. Their suffering has a profound dimension of public responsibility; it belongs to everyone. This first encounter in the course of the field work revealed a political potential, and a new aesthetic experience. What was at stake was an aesthetics of knowledge, invoked by the way in which these encounters mount to an altered sensible experience (Shapiro 2013) in which the mothers define space as essentially political. This sensible experience is brought to fore through what Boltanski (2004) calls a 
'politics of piety' in which compassion and empathy underpin the need to collectivise individual instances of suffering. Meeting those mothers at that moment was an invitation, and a demand for action.

Given this, that event became a moral imperative that changed the course of the rest of our research. Essentially, the encounters with these women dramatically transformed our approach to IR and our understanding of the dimension of the political. Tracing the paths of these mothers helped us to grasp their intimate relationship with politics, specifically their relationships with the 'state' (Brown cited in Lacerda 2012: 165).

This study also represents an effort to engage with a multi-sited ethnography (Marcus 1995), in the sense that the field work was not conducted at one site only but in numerous favelas in the city on which similar violence has been inflicted. The research method pursued was therefore to follow the mothers wherever they went (to public events and activities, public hearings, marches, vigils, and so on). Methodologically, this study represents an experimental approach in the field of IR, as it seeks to combine different fields of knowledge (such as anthropology, urban sociology and IR itself) into a dialogue. This multifaceted theoretical framework allows us to enhance the analytical tools we can use to reveal the silences of the discipline (Krishna 2006). It is helpful to bear in mind that a history of pacification always conceals a history of violence in which some voices rest in silence. This study concentrates on those silences, and it is essential and urgent to listen to what these voices are telling us.

In what follows, we will report on and analyse the narratives of these mothers. Their accounts of events on the day when their sons were killed reveals the events previously hidden behind a curtain in the course of the war waged by the state. These mothers get together in a common struggle for justice, as they have all suffered the effects of the state of war in the city of Rio de Janeiro.

Their group has no name, and they have not organised themselves institutionally, but they mobilise through a network of solidarity in which they keep in contact with each other, in order to join their efforts in this common struggle. Most are black slum dwellers who had lost their sons to the armed wing of the state. Their experiences have their own particularities, but all of them share the common condition of being mothers who have experienced arbitrary state violence that has destroyed their families and their lives. This shared pain is what allows them to organise politically.

They protest on the streets, in favelas, and on city squares. They organise vigils and marches on important dates, to remember and honour those who were killed. They come together once a year in front of the Church of Candelaria, to pay homage to the victims of state violence in various massacres in the city. They invite as many people as they can to attend their protests before and after public hearings about the killings. These moments are important, as they bring political mobilisation to the judicial bodies involved.

Strategically, these mothers do not only occupy public spaces in order to reorder political space and time, but also to reach the highest levels of the state. The speeches cited in this article were recorded at protests, vigils, public hearings, and other events. The main 
voices registered here are those of Deize, Maria Dalva and Mônica Cunha, all of them mothers of victims of state violence.

We follow the mothers in order to establish how the Brazilian state disrupts the spatio-temporality of these political subjects and, in consequence, how their political engagement presents events in the favelas in a gendered perspective. Their struggle becomes a point of departure for all subsequent analysis, aimed at revealing the effects of current state practices and a security discourse that results in arbitrary violence inflicted on supposed Brazilian citizens in the context of a supposedly democratic nation state. This struggle call into question a number of conventional categories in modern political discourse, such as the distinction between the public and private domains, and notions of the past, present and future. Instead, the research draws our attention to an alternative notion of disrupted temporality, evidenced by the struggle of these women against the progressive temporality of the nation-state.

\section{The cry of the mothers: echoes of a disrupted time}

The operations of the Brazilian military police and armed forces in the favelas in the course of the 'war on drugs' have resulted in the deaths of growing numbers of young black men. According to Amnesty International, about 30000 young people between the ages of 15 and 29 were killed in 2012, and of those, 77\% were black. ${ }^{2}$ This illustrates the consequences of the negative stereotypes of these young people as well as the favelas. These youths are being killed because they are suspected of drug trafficking. However, most of the young people targeted in the course of this 'policy of extermination' (Zaccone 2015) have no connection with drug trafficking.

The naturalisation and acceptance of the management of deaths in the favelas result in the trivialisation of this reality as a necessary evil in the course of social and urban planning aimed at achieving a peaceful and orderly society. One perverse effect of this model of public security is the extermination of thousands of black slum dwellers as a prophylactic for security problems in the city of Rio de Janeiro. According to Tatiana Moura (2010), besides those killed, ${ }^{3}$ many others have suffered the effects of the 'continuums of violence' created by this state of war. Although these people are not directly involved or engaged in this war, they are severely affected. It is estimated that, between 1979 and 2000, anything between 300000 and 600000 people succumbed to the violence of the city. Therefore, armed violence has penetrated the everyday lives of city residents to the point where they live in a state of constant fear and tension.

Armed violence on a micro scale, such as in the favelas, forms part of a global phenomenon, and brings to the fore the need for new perspectives on these settings of conflict in order to grasp what is at stake in these new contexts of violence in urban spaces. Despite the conventional notions of war embedded in the discipline of IR, we live in a world where different forms of violence have pervaded everyday life to such an extent that we need to go beyond traditional notions of war. 
I was born on 18 February 1971, practically inside Cantagalo's samba arena. This was the time of the year when rehearsals for the famous 'banho de mar à fantasia' ${ }^{4}$ were usually taking place there. A gunfight suddenly started between the police and some of the guys who were initiating the drug trafficking inside the community at that time. My mom began to feel labour pains, and she then gave birth during her seventh month of pregnancy, due to the fright caused by violence (Deize Carvalho).

This account strikingly depicts the favela as a stage for a kind of war in which violence ceases to be an exception, and becomes a feature of daily life. Violence, in these contexts of war in the city, is less of an instrument than an expression of a culture of violence (Moura 2007). The story of Deize's birth is a good example of how violence is naturalised in such a context. In a society in which people are born in a context of conflict and armed violence, war is less of an isolated fact than something that pervades the cultural system of everyday life (Moura 2007: 31).

Analysts have begun to describe this in terms of new wars, that is, conflicts in which intense armed violence is concentrated in limited or micro territories such as the favelas, while institutionalised and formal peace appears to operate at the national level (Moura 2007: 30). Obviously, the scale of these manifestations of violence is quite different from more traditional forms of war. Nevertheless, despite the questions related to the separation between war and 'smaller forms' of violence, it is precisely this notion of 'continuums of violence' as an expression of a conflicting reality what is important and should be considered here.

Despite these departures from the concepts, practices, actors and strategies in the traditional framework of war, sexual attributes seem to remain present, as asserted by Moura. According to her, all wars or armed conflicts rest upon constructions of identities and mechanisms of power and domination that constitute the core of a patriarchal system, or a system of war (Moura 2007: 26). This system constructs a (dominant and violent) masculinity at the expense of silent, invisible, and marginalised femininities. In Moura's perspective, sexual attributes manifest themselves in formal armed conflicts as well as undetermined contexts.

This gendered cross-section is evident in Deize's account of how her mother gave birth to her while the police and some men played out a territorial dispute. The sexual attribute informs who is on stage, and who is backstage. While, as Moura argues, some women may play roles in contexts of war that are usually assumed by men, the women followed in the course of this study are indirectly involved in this war, but suffer directly from its impacts.

In this study, then, our task is to open the curtain and identify some hidden actors who experience the direct impacts of this war. Deize's account reveals that the violence (re)produced in and through a masculine sociability also affects women, whose lives are deeply affected by it. Her speech is highly significant, as it highlights the banality and naturalisation of state violence in the favelas. The state approach to the favelas as territories of 
violence has huge impacts on the private lives of families, mothers and children. Deize not only ran the risk of being killed, but was born in the midst of a conflict. This indicates that the birth of slum dwellers is already conditioned by the violence played out in these territories.

In this sense, it is worth wondering to which extent slum dwellers are, since birth, doomed to deal with state violence as an inescapable ontology. What impact does state violence have on their private lives? What is revealed about the relationship between the state and these people? As Deize's account reveals, some lives are already marked by the possibility of being taken away before they begin.

In Deize's case, her life was already threatened by state violence before she was born, and her birth was conditioned by it. This leads us to think about the effects of this war on the backstage of this battlefield. Whose lives have been sacrificed in order to sustain such a context of war? Deize's account of her birth reveals that death is present throughout her life, inasmuch as the state that abandoned her as a child is the same state that took her son's life. When these lives are marked by the possibility of being ended, we need to take a critical look at what has been removed from this stage of war, and to listen to what these voices tell us from the back of the stage.

The war waged by the Brazilian state does not escape this gendered framework, and we should not neglect the structural and cultural traces of violence operating on a larger scale and in the longer term that form the bedrock of the naturalisation of other forms of violence in the micro and private spheres, as felt by those who are made invisible by this politics (Moura 2010: 187). Even though the mothers do not bear arms, they are directly affected by the war in the form of grief over their irretrievable losses. These women are part of this bloody history; they are embedded in a grammar of war in the sense that their lives have become a stage of terror since the loss of their sons.

According to Moura (2010), the most direct impact of state violence is on those who die, but it also affects those who survive, and are therefore also victims. Thus the dimension of violence was not only part of Deize's life, but also of her whole family. Her son Andreu was murdered by state agents while serving a sentence at the General Department of Social-Educational Actions (DEGASE), an institution intended to resocialise children and youths younger than 18 in conflict with the law. Andreu went to DEGASE twice, and the second time he was brutally murdered by agents of the state who worked there as supervisors. The official version was that Andreu tried to escape, and fell off a wall. Deize managed to prove that his injuries showed that he was brutally beaten.

This is the backstage of the state of war in Rio de Janeiro. The idea of a divided city, living in a state of war, is a central construct in its symbolic repertoire, especially since the 1990s, when the state first declared war on drug trafficking in the favelas (Leite 2012: 375). The idea of a city embedded in a state of war generates a demand for public order, addressed via the so-called pacification of the favelas by the Pacifying Police Units (UPP), which were first established in 2008. The pacification programme is meant to take place in two phases: (1) the military occupation of the slums by the UPPs, aimed at regaining control of those territories for the purpose of blocking drug trafficking; and (2) providing 
slum dwellers with access to public institutions and services via UPP social programmes (UPP Social).

However, this war has spilled on to other residents who are seen as bandits or accomplices in trafficking activities (Leite 2012: 375). The discourse of war, in turn, has allowed the use of interventionist policies of exception in the slum territories, thus redefining the limits of public policies within these spaces.

We were always very much afraid, because when the police came to the community, they came as if they were arriving in an enemy country, they were there to kill. That's so the case that these policemen, when they arrived in Borel [a favela in the north zone of Rio de Janeiro], they arrived there to kill. Sixteen policemen were involved in that operation [...]. People there were beaten, threatened, and that was the day, the day when I was also threatened by them. And the Choque [another name for Rio de Janeiro's Military Police's Special Operations Battalion] arrived with a rifle and spoke to me like this: 'Are you the one who wants to mess up with everything?' And I replied: 'I don't want to mess up with you, I didn't ask you to kill my son, you are going to be convicted.' And he told me this: 'The one who killed is going to be convicted just because he didn't do it well.' And I felt... I thought, 'my God, I didn't know things were like that' (Maria Dalva, Tiago's mother).

Dalva, the mother of another victim of state violence, spoke of the day when the police entered the favela of Borel and murdered some young people, including her son Tiago. She also spoke about the threats made by the policemen who had murdered her son. When she began to search for evidence that could incriminate those responsible for the deaths of some youths, she was threatened and intimidated by some policemen. It is common for mothers to receive death threats when they decide to engage in the struggle for justice. Thus the policeman quoted above openly admits that a policeman killed Dalva's son, and goes on to say that the only reason why he might be tried and convicted is because he did not do it properly.

The state, via institutions such as the police and the army, aims to identify areas in which drug trafficking takes place, and enters these spaces with militarised apparatus in order to control and pacify them. These security policies are guided by a territorialisation of violence, which maps the favela as a source of public security problems within urban planning which threatens the order and the stability of the city. This perspective leads to a public security model in which the state is legitimated to act with discretionary power in relation not only to these territories, but also to those who live there, as is evidenced by Dalva's account of the day the police committed a massacre in Borel and killed her son, among many others.

Identifying these urban spaces as territories of exception positions favelas as places where the state can use any measure of control, and legitimises the mechanisms that con- 
stitute them as spaces defined by violence and a radical 'otherness' in relation to the city and society at large (Leite 2012: 376). As Machado da Silva (2008: 14) reminds us, 'fear produces expectations and demands of security against, and not with, others - leading the police to function as a true containment device'.

A notable feature of Dalva's account is her observation that the police 'came as if they were arriving in an enemy country; they were there to kill'. This suggests that an exceptional political situation has been created, and exceptional measures adopted to deal with it, accompanied by a construction of two opposing sides, namely 'good citizens' and 'enemies'. In this frame, slum dwellers become the enemy, which has to be fought and defeated. This allows us to adopt a metaphor of a war of all against all (Leite 2012: 379). This speaks of a society in which the most fundamental rights of individuals, namely the right to life, is put at risk by the state itself, which is supposed to guarantee it (Leite 2012).

The state's intent to exercise discretionary action in the interests of a particular perception of 'public security' is evident in a speech by the Security Secretary José Mariano Beltrame, when he said that 'the remedy to bring peace often involves some action that brings bloodshed' (Beltrame cited in Farias 2014: 161). In other words, in this model of security, some people must die so that others can live in peace. When he asserts that bloodshed is necessary to provide security and peace (to a specific part of the population), it foresees and enables the sacrifice of some citizens who may have nothing to do with this war. This bloodshed is placed at centre stage by the movement of the mothers and relatives.

I will put myself here as sister of a victim of state violence. This moment of the manifestation is quite profound for me, because it was through my pursuit of answers to understand why my brother was murdered that I became the person I am today. Obviously, it came along with all these wounds, with all the revolt, but it was a kind of revolt that builds strength. Every tear that I drop brings me the certainty that I don't accept [she speaks yelling and crying], and that I don't care... don't you come and say that one deserves to die and the other doesn't! [Yelling]. We don't have death penalty here and this must be very clear so people don't say that one must die while others don't! My brother didn't deserve to die! [Crying] (Speech of the sister of a young man murdered by the police).

This statement, by the relative of a victim of state violence, demonstrates the power of the state over these citizens' bodies. In a Foucaultian sense (see Foucault 2005), the slum dwellers' bodies are manageable under the arbitrary practices adopted in the favelas, which target this population as one that has to be controlled in order to remove other bodies from risk. The racist framework in which these practices are situated can be understood as a mechanism of biopower in which some people deserve to live more than others. The project of pacification is about controlling and managing lives and bodies as a prophylactic for the ills contaminating the city. Nonetheless, this perverse war is not free of reaction and resistance, as the statement quoted above shows. 
The state war on the bodies of slum dwellers eventually has a violent and arbitrary impact on the lives of mothers, interrupting the temporal production of family ties between mothers and children. A line of time is cut, and the ends are confused - past, present and future no longer seem to have any meaning, resulting in a temporal vacuum in the lives of mothers (and the rest of the family) in which their times are eventually reconfigured. This void is expressed in a collectivised and shared political struggle waged by the mothers, whose sense of solidarity leads to resistance and a new political existence.

The divisions in the temporal narratives of the mothers will always be present, even if past and present are tied together anew, for the existing node will always condition the inescapability of a sad past very much alive in memory, a painful present, and a future of hope and despair.

However, this disruption of temporality also creates the possibility of agency in search of overcoming this condition of disrupted time. It is the condition of disrupted time itself that provides mothers with this character of agency in pursuit of the very meaning of time.

What we are left with here is two wars: that of the state against the favela, and that of the mothers, who fight for justice on behalf of their children, against the state. According to Vianna and Farias, this reading allows us to identify two opposing symbolic units: the state, anthropomorphised by the masculine figure, and the mothers, represented by the feminine figure and the feeling of pain that takes on a political role:

The women speak, in this way, of a political insurgency defined in close connection with constructions - always in the process - of gender. In speaking on behalf of a domestic order that was brutally undone by the murder of their children, they (and other family members) bring in the feminine not as their individual bodies, but as a significant mark of the relationships that was broken, as well as of the illegitimate violence that destroyed them. They thus take the 'home' to the scene of protest, by way of what is considered to be its symbolic 'exemplary center': motherhood itself (Vianna and Farias 2011: 93).

The idea of bringing the 'home' to the scene of protest - that is, to expose the intimate and private lives of families in public and collective spaces - is of great political significance in that it politicises these events, and illuminates the nature of social and collective responsibility. This movement rearranges the boundaries between the public and private domains in the sense that private emotions and private spheres of life are invaded, and publicly exposed in turn. Once the 'home' is invaded by state violence, it is as if the state of war embedded in the city through the politics of pacification is carried into these mother's private lives. Although mothers feel the pain of losing a child in a unique and exclusive way, carrying this pain into the public domain makes it possible for the mothers to wage this public and political struggle.

Another important issue is the representation of the state in terms of gender relations (Vianna and Farias 2011: 93). 'Home' is seen as a non-political sphere and the public space as a political one, establishing a separation between the public (political) and the private 
(personal), as if the deaths of these children to be felt in the private sphere does not possess an eminently political character. In this perspective, the public domain is related to the masculine and the private and domestic sphere with the feminine, with the mother as the symbolic expression of the latter.

The struggle of the mothers, in blurring these boundaries, suggests to us that the private is public, and that their personal pain over the loss of their children also has a political character. In this way, the mothers at war are playing an important role in disrupting the spatiality of politics, and politicising the space through which they move. In this sense, they end up "blurring the moral semantic fields of "family" and "the state", and bursting prior allocations of "family" as a sign of moral and emotional value, and "the state", the administrative bureaucracy, as force or coercive power' (Vianna cited in Farias 2014: 121).

The presence of the mothers on the streets, in actions and protests about the deaths of their children, breaks with the gendered paradigm of politics in that, in occupying the public sphere and tensioning political boundaries, they take on a protagonist role in politics they had previously been denied. Women have long been assigned the role of taking care of children and the home, and this domestic environment has traditionally not been given any political value. In being present in a public space, bringing to the fore emotions and intimate feelings, these mothers denounce the institutional violence of the state against their bodies and their families, challenging the idea that the state, with its sovereign prerogative, has the right to act in this way.

The mothers' war thus challenges this masculine assignation that attacks instead of protects, and brings the war 'home' (Vianna and Farias 2011: 95). In this sense, they challenge the sovereign and masculine status of the state, opening a possible pathway towards resignifying their political struggle not only as a way of living out the pain of loss, but as a process of reinscribing themselves on the world (Farias 2014: 146).

State brutality in the course of the 'war against drugs' is made visible, then, in the perverse way in which the metaphor of war invades the private domain, changing the social relations of the family, and interfering with the production and meaning of time.

We, the mothers, are here not only to remember the year that Johnatha was cowardly murdered by the UPP [Unidade the Polícia Pacificadora - Pacifying Policy Unit] of Manguinhos with a gunshot in his back, we are here not only to remember the year that Ana Paula was here crying, as in every single night, as I was also there crying standing by the door waiting for my son to come back, looking to his bed to check if he's by any chance lying down there [...]. I almost didn't come here today, but I told myself "No, I have to go there to join with Ana Paula, I have to overcome this feeling", because it can be hard, but it is not impossible when a mother resorts to her inner power and finds the strength to fight. There are these days I just want to stay in my house, bearing the hope that I will see Andreu coming in by that door, but I know he won't and this hurts more and more each day. I am restoring my house for me to not remember anymore, 
because I can't stand to stay inside my own house [crying]. I'm trying to change my dreams, my plans, in order to easy this pain, this feeling of missing my son (Deize Carvalho).

The perversity of the war is noticeable in the clash between mothers and the state in that mothers give life, and the state strips it away (Vianna and Farias 2011: 108):

The anger, emptiness and suffering aforementioned in relation to those who were killed thus gained other contours and time. There was talk here of a future loss, a place that was extinguished forever and ahead of time, in the becoming, in the imagined (Vianna and Farias 2011: 12).

While the institutional violence of the state interferes with the temporality of the mothers, we can see that the deaths of their children disrupts domestic relations, and reconfigures the temporality of the family in blurring the past and present, and suspending a future of hope and despair. Another temporality is produced in the lives of the mothers, in that they develop a different relationship with time in which the strict separation between the past and the present is broken by the murder of their children, and the future is always to come, dependent on the reparation and recognition of these murders by the state.

According to Constantin Fasolt (2004), modernity is anchored in the distinction between the past and the present, which are also in relation to one another. The present is constituted as the 'here and now', that which the past is not, and acquires mutability in relation to an unchanging past. While for Fasolt, these times (past and present) are well demarcated in modernity, there does not seem to be any line separating the future from the present; consequently, the present is always open, changing every second, while the past, because it is unchanging, never returns. Thus the ideas of freedom, mutability and progress depend, according to Fasolt, on this distinction between past and present.

For the historian, it is this distinction between past and present that produces the idea of an autonomous and free modern subject, who takes control over her/his destiny. This subject assumes the ability to change the world, when, according to Fasolt, it is about enclosing a part of reality and calling it 'past.' Therefore, freedom in time depends on the emancipation of these subjects in the face of the past. The historical method, namely the prohibition of anachronism (or the location of things in their proper context), makes the world safe for the autonomy of its modern occupants, because it prevents the present from mixing with the past, which could generate a chronological pollution between these times. However, for Fasolt, history does not fall into separate contextual packages, with each one obediently lined up in terms of yesterday/today in ways that cover the entire past without confusing overlaps or embarrassing gaps.

The recasting of the temporality of the mothers gives them another sense of being in time that moves away from this modern narrative. Their personal trajectory through time is marked by an overlap between the past with the memory of the living child, and the present without the child, who was taken by the state. For the mothers, keeping the past alive in the present is what makes it possible for them to wage their war. Their past 
returns, fostering a struggle in the present. In recounting the day when their children were murdered, and remembering their life stories, the mothers bring the past into the present, and blur these clearly demarcated modern borders. For these mothers, to live in the present through their past is what keeps them alive and fighting.

Despite the fact that their present is informed by a past that is very much alive, and provides them with the means of resistance, this present time of struggle is also crossed by an experience of suffering that put them on a stage of terror, once they are forced to live every day with the pain of their loss. In this sense, the mothers inhabit a time of atrocity that is constantly reproduced in their lives:

Survivors live in the chronological time of ordinary life experience, but they also still inhabit, and are inhabited by, durational time, a frozen time, a continuously experienced duration of atrocity that can be neither transcended nor generalized (Kleinman, Das and Lock 1997: p. xvii).

Thus the mothers are stuck in this time in which atrocity is continuous and forces them to live in a spatio-temporality of terror due to the absence of their sons. It is precisely through this time of terror, embedded in the grammar of war, that the mothers live in permanent mourning, a state from which they cannot escape once those deaths are unacceptable for them (Butler 2004). In this sense, although the mothers are not necessarily a direct target of the war, their lives are deeply affected by it. As Moura (2007) asserts, the private thus becomes a stage for war.

For Fabio Alves Araújo (2012), following Michael Taussig, what characterises the terror lived by the mothers is the presence and proximity of death, in the sense that the danger of having a son killed is always imminent. Another consequence of living in this 'space of death and terror' is its ineffability - the mutilation of language that produces the silence of these victims (Araújo 2012). That is to say, one of the elements that enclose the mothers in a present time of constant and endless suffering is the destruction of their very capacity to communicate their experiences. For this reason, it is hard for many mothers who have experienced such a tragedy to speak out about what happened. Moreover, they are often threatened by policemen, as we have seen in Dalva's case, which makes it even more difficult for them to engage with the struggle.

Nonetheless, the mothers are not a monolithic group, and vary among themselves. Even though they are all mothers who have had a tragic experience, some live in better social and economic circumstances than others, and are more or less affected by their experiences. The accounts cited above are those of mothers who manage to face the difficulties and risks, and overcome the incapacity of speaking, which is a daily struggle. As Deize states, 'I have to overcome this feeling, because it can be hard, but it is not impossible when a mother resorts to her inner power and finds the strength to fight. There are these days I just want to stay in my house.'

The overcoming of this terror is an everyday process, even for those mothers who are more engaged in the struggle and more visible in the media; the consequences of this terror and its effects follow them daily. In this context, the mutilation of language is the 
consequence of a traumatic experience that shuffles and disrupts the temporalities of the subjects, putting them into a paradoxical and indefinite field in which the incapacity of remembering and sharing that lived experience exists side by side with the impossibility of forgetting that event - once it is inevitably inscribed on the subject's own body. According to Paula Lacerda (2014), following Veena Das, the violence inflicted on their sons manifests itself concretely in the lives and bodies of the mothers:

Suffering almost always comes along with another category, that is 'pain', that materializes the outcomes of this unparalleled violence in the body, but also in the soul. The 'headaches', 'migraines', 'heart complications', 'respiratory problems', 'high blood pressure, 'distress', 'depression', 'lack of will to life', as well as 'sexual indifference' reflect in the bodies of the relatives, especially in women's bodies, the physical torture once inflicted on their children. [...] It is a type of pain that can be felt in a body other than the one on which such violences were committed (Lacerda 2014: 52).

Thus, one of the most serious consequences suffered by these mothers is that many of them become ill, due to the pain caused by the loss they have suffered, the mourning that drags on for many years, and the feeling of powerlessness in the face of the impunity of the state.

These women are sick, they need assistance, we need a system that offers medical care to these mothers. Because they end up alone, they end up talking to themselves, and returning to their homes all by themselves, and they get sick. So, we need to offer medical care to these women, because my mother didn't get any assistance, and she died. And many other women have been dying in these same conditions. So let's think of these children, let's think of ways to protect and take care of these mothers (Mônica Cunha, mother of a victim of state violence).

Mônica Cunha is drawing attention to the fact that these mothers are dying day by day due to the suffering caused by state violence. Her plea shows that these mothers often become seriously ill, and their frequent deaths are a direct outcome of the suffering and distress to which they have been submitted. Living with the state of psychological torture of having to deal with the inacceptable loss of a child is a sign of slow death. ${ }^{5}$ The impunity of the state burdens them with another form of violence.

This movement ultimately affects how the mothers see themselves as belonging to a nation-state that kills their children. The temporal disruption thus impacts on their notion of citizenship. The mothers, in joining together in solidarity and undertaking a fight for justice, destabilise the notion of space and time of the nation-state, the foundation for an idea of citizenship that is ultimately called into question by their actions. The modern notion of citizenship is defined by the idea of the nation-state in the sense that being a 
citizen means belonging to a specific spatio-temporality. We therefore need to examine the juncture between state and nation, and its implications for the notion of citizenship.

According to Michael Shapiro (2001: 118), the idea of the state forges a spatiality that sustains the territorial entity required for the legitimate monopoly of violence, and incorporates various subsidiary units in an administrative and legal entity within its borders. On the other hand, the modern idea of the nation requires a coherent, unified, and historically shared culture. In this sense, the junctures of the nation-state represent a management of historical narratives that give temporal coherence to a unified and homogeneous culture within well-defined territorial boundaries. In other words, it is as if the nationstate, being the arbiter of citizenship, forges a sense of homogeneity and temporal coherence, and fixes it in space.

The statist notion of citizenship gains shape in the recognition of the individual as a lawful presence within the state (Shapiro 2001: 118). By identifying young black slum dwellers as suspected traffickers, the state mobilises a politics of combat that positions them as enemies to be exterminated, as they inhabit a territorial space not legitimated by a statist framing, but which is in dispute. It is as if the state does not recognise the presence of these people, because they do not live in 'formalised' spaces. However, the presence of the mothers on the streets generates other kinds of narratives which challenge the statist performances that seek to forge a national coherence. Their presence in public space disrupts the political ordering that allows some people to be there, and others not. The mothers create their own political domain inasmuch as they emerge from backstage and occupy the main stage with their hidden voices and bodies. They end up playing the role of (re)politicising urban space.

The presence of these mothers on the streets, crying and screaming that the state has no right to take the lives of their children, challenges the temporality of the nation-state, informed by a logic of citizenship located in territories defined by the privileges of sovereignty in a homogeneous community, and based on notions or assumptions of cohesion and a shared cultural history (Shapiro 2001: 119). Besides (re)politicising these urban spaces, and transgressing the spatial boundaries of the public and the private, the presence of the mothers make evident the fractures within the nation-state in disputing the meaning of citizenship. They do not recognise themselves within this temporal coherence of the nation-state, informed by a Hegelian spatio-temporal narrative (Shapiro 2010). Their time is disrupted, and thus reveals other temporalities that clash with the official narrative of the cohesive linearity and fixed spatiality of the state. If the national temporality is guided towards the future in which the state matters as a telos, the mothers are deprived of a future in which they could hope to overcome their pain. At the same time, they seem to be stuck in a present time of atrocity, which is precisely what allows them to transform their suffering in a political struggle. Their disrupted spatio-temporality unravel the fragility of the progressive temporality of the nation-state which is endlessly (re)produced in these mothers' suffering.

Despite the fact that their traumatic experiences place them in a vacuum in relation to a national temporality, once their temporality is disrupted by a state that kills, they 
manage to resignify time through the similar narratives of other mothers who empower themselves in a common struggle. The relationships established among themselves give them another sense to life, which allows them to overcome their suffering. This temporal reframing forges an identity that escapes from and questions the linkages of these women to any romantic notion of national identity. The process of subjectification which these mothers go through puts the construction of a national history of unity and homogeneity into question.

The mothers, in this sense, break with the universal model of a Hegelian notion of historical time in that their very presence within public space undoes the attempt to conceive the nation-state as the ultimate purpose of history. By introducing flashes of the past through the memory of their children in their narratives, the mothers give political meaning to their existence in the present, and blur the telos of the nation-state. The deaths of these young people cannot be forgotten; indeed, the idea of nation is built upon their blood, revealing its violent foundation (see Campbell 1996). The Brazilian state sustains a narrative of a cohesive and homogeneous nation at the expense of the personal lives of these women (Enloe 2014). This unified, cohesive and homogenous nation is a nation that kills. The very struggle of these mothers destabilises the junction between state and nation, and highlights the violence of this hyphenation.

In sum, the ways in which these mothers resist the temporality of the nation-state represents a break in our perception which reveals the secret connections behind our everyday reality (Shapiro 2011: 117). Leaving their homes and carrying the pain of losing their children at the hands of the state into the streets is not only a political act, but also an aesthetic one. The public dimension of emotions once regarded as private is revealed by the brutality of state intervention in the lives of these families. Motherhood acquires a political relevance that gives meaning to the lives of these mothers, and this keeps them alive in the hope for justice. As long as they are unable to find the justice they are seeking, their grief will continue to be translated into struggle.

These mothers give another meaning to space, and become political subjects whose actions bring out the domain of the political. Unlike the Arendtian vision of predetermined political spaces, these mothers break with the fixed boundaries of political and non-political space as they are the ones who create political space through their actions, to the extent that their actions are what brings about the political domain. In this sense, the mothers closely match what Rancière calls the political as an event of dissent (Shapiro 2011: 112), in which multiple identities and temporalities reorder the spaces in which these subjects operate. Although the 'government of deaths' (Farias 2014) in Rio de Janeiro deprives these mothers of the opportunity to live in the present and shape their future, they transform themselves not only into political but also aesthetic subjects (Shapiro 2013), because they alter our perception of how politics and the political are perceived, and alert us to a reorganisation of the city in which the inscriptions of their existence become possible. 


\section{Conclusion}

In this article, we have sought to examine the effects of the war waged by the Brazilian state in which the police and armed forces are mobilised to 'pacify' some urban spaces regarded as territories of violence. The official narrative is that in order to bring peace, it may be necessary to bring bloodshed. Our objective is then to focus on the political implications of this war for the private dimension of families that have suffered losses in its course.

The category of the mothers of victims assumes great importance, as they are engaging in a struggle for justice as a means of escaping from a state of mourning they may experience for the rest of their lives. Even if they manage to hold the state accountable for the deaths of their sons, it would not relieve their pain. This suggests that both the incapacity of remembering and the impossibility of forgetting places mothers in a situation which they are obliged to live out. For those who manage to give their traumatic experience a political purpose, the only alternative is to gather the pieces of a private spatio-temporality disrupted by the state, and transform it into something that gives them a sense of making life worthwhile.

Methodologically, we have been guided by the important feminist question posed by Cynthia Enloe (2014), namely: 'Where are the women?' This study has forced us to think about the role and place of these women in politics - to identify their role in the construction of what we understand as politics. In the course of doing so, we have realised that the struggle of the mothers allows us to grasp the complexities of this war which is not simply a matter of 'pacification', but a form of power that not only hides some actors, but is accumulated and exercised at their expense.

This study also seeks to construct a transdisciplinary knowledge, and to open up space for a new research agenda in IR focused on practices of resistance in everyday life in which, as Tickner (2001) suggests, gender can be identified as an analytical category. Rather than seeking to insert gender into IR, the aim is to acknowledge that gender is already there, and constitutes one of the silences of the discipline. In this sense, gender as an analytical category allows us to recognise the political implications of these women, and the disturbance they cause in politics.

The mothers' narratives form part of the construction of a national narrative that is deeply rooted in a history of violence, domination and exclusion. In fact, it is upon the tears of the mothers and the blood of their sons that the Brazilian nation-state is constructed. Their emergence from their homes, which have been brutally invaded by this war, is politically highly significant. Despite being silenced and marginalised, the voices of these mothers represent the decolonial expression of a disrupted temporality in which their place in the process of constructing the Brazilian nation operates through their spatio-temporal indefiniteness and the invisibility of their stories. Their spatio-temporal condition and their stories counter the spatio-temporality of the nation-state, carrying its arbitrariness and constitutive violence into the public domain. 


\section{Notes}

1 [Note by Vinícius Santiago:] This article is based on my field work among mothers in the favelas of Rio, originally conducted for the Master's Programme in International Relations at the Institute of International Relations of the Pontifical Catholic University of Rio de Janeiro. It was written together with Professor Marta Fernández, who helped me to develop this project. I am very grateful to her for having undertaken this journey with me, and for her rich contribution to these reflections.

2 Available at $<$ https://anistia.org.br/campanhas/jovemnegrovivo/ $>$.

3 For more information about the death rates due to armed violence in Rio de Janeiro, see Ignacio Cano (2012).

4 'Banho de mar à fantasia' is an old custom dating from the 1950s in which revellers dressed in costumes made of paper enter the sea, animated by bands playing carnival songs.

5 This reinforces the idea that mothers live in a space of terror in which death is imminent, not only their sons' deaths but their own deaths as well.

\section{References}

Butler, Judith. 2004. Precarious life: The Powers of Mourning and Violence. London: Verso.

Campbell, David. 1996. 'Violent performances: identity, sovereignty, responsibility'. In Yosef Lapid and Friedrich Kratochwil (eds), The Return of Culture and Identity in IR Theory. Boulder: Lynne Rienner. pp. 163-80.

Cano, Ignácio, Doriam Borges and Eduardo Ribeiro. 2012. Os donos do morro: uma avaliação exploratória do impacto das Unidades de Polícia Pacificadora (UPPs) no Rio de Janeiro. São Paulo: Fórum de Segurança Pública; Rio de Janeiro: LAV/UERJ.

Enloe, Cynthia. 2014. Bananas, Beaches and Bases. Berkeley: University of California Press.

Farias, Juliana. 2014. Governo de mortes: uma etnografia da gestão e populações de favelas no Rio de Janeiro. Rio de Janeiro: UFRJ.

Fasolt, Constantin. 2004. The Limits of History. Chicago: University of Chicago Press.

Foucault, Michel. 2005. Em Defesa da Sociedade. São Paulo: Martins Fontes.

Kleinman, Arthur, Veena Das and Margareth Lock. 1997. Social Suffering. Berkeley: University of California Press.

Lacerda, Paula Mendes. 2012. O “caso dos meninos emasculados de Altamira”: polícia, justiça e movimento social. PhD Thesis, UFRJ/Museu Nacional, Rio de Janeiro.

. 2014. 'O sofrer, o narrar, o agir: dimensões da mobilização social de familiares de vítimas'. Horizontes Antropológicos, 20(42): 49-75.

Leite, Márcia Pereira. 2012. 'Da "metáfora da guerra" ao projeto de "pacificação": favelas e políticas de segurança pública no Rio de Janeiro’. Revista Brasileira de Segurança Pública, 6(2): 374-89.

Machado da Silva, Luis Antônio (ed). 2008. Vida sob cerco - violência e rotina nas favelas do Rio de Janeiro. Rio de Janeiro: Nova Fronteira.

Shapiro, Michael J. 2001. For Moral Ambiguity: National Culture and the Politics of the Family. Minneapolis, Minneapolis: University of Minnesota Press.

. 2010. The Time of the City: Politics, Philosophy and Genre. London and New York: Routledge. 
2011. 'The presence of war: "here and elsewhere”. International Political Sociology, 5 (2):

109-25.

2013. Studies in Trans-Disciplinary Method: After the Aesthetic Turn. London, New York: Routledge.

Tickner, J Ann. 2001. Gendering World Politics. New York: Columbia University Press.

Vianna, Adriana and Juliana Farias. 2011. 'A guerra das mães: dor e política em situações de violência institucional.' Cadernos Pagu 37 (July-December): 79-116.

Zaccone, Orlando. 2015. Indignos de vida: a forma jurídica da política de extermínio de inimigos na cidade do Rio de Janeiro. Rio de Janeiro: Revan.

\section{Acknowledgements}

The authors would like to acknowledge the support of the project Jovem Cientista do Nosso Estado (JCNE) of the Fundação Carlos Chagas de Apoio à Pesquisa (FAPERJ), which enabled us to write this essay.

\section{About the authors}

Vinícius Santiago is a doctoral student at the Institute of International Relations of the Pontifical Catholic University of Rio de Janeiro (IRI/PUC-Rio), Brazil. His master's thesis at the same university dealt with state violence in the favelas of Rio de Janeiro, and the mobilisation of mothers in the struggle for justice after the death of their sons. His field work involved following the mothers over a period of two years in order to gain a better understanding of their relation with the state. His research interests include postcolonial studies, post-structuralism, aesthetics, gender, racism and violence.

Marta Fernández is an Adjunct Professor at the Institute of International Relations of the Pontifical Catholic University of Rio de Janeiro (IRI-PUC/Rio), Brazil, where she obtained both her doctoral and master's degrees. She is currently co-ordinating the graduate programme at the same institution. She was a research scholar at the University of St Andrews in Fife, Scotland, in 2010. Her doctoral thesis, defended in 2011, was entitled 'A Postcolonial Reading of the United Nations "New" Peace Operations: The Case of Somalia'. She has taught international relations theory and postcolonial studies. Her current research deals with Brazil's participation in peacebuilding operations, development, South-South co-operation, theatre, post-colonial perspectives, and racism.

Received on 15 June 2016, and approved for publication on 1 November 2016. 